\title{
EFEK PENGGUNAAN MODEL PEMBELAJARAN INQUIRY TRAINING BERBANTUAN MEDIA VISUAL DAN KREATIVITAS TERHADAP KETERAMPILAN PROSES SAINS SISWA
}

\author{
Derlina $^{1}$ dan Lia Afriyanti Nst $^{2}$ \\ ${ }^{1}$ FMIPA Universitas Negeri Medan, ${ }^{2}$ SMP Amir Hamzah Medan \\ email: derlina.nst@gmail.com
}

\begin{abstract}
Abstrak: Penelitian ini bertujuan untuk mengetahui efek penggunaan model pembelajaran inquiry training berbantuan media visual dan kreativitas terhadap keterampilan proses sains siswa SMP. Penelitian dilaksanakan di SMP Amir Hamzah Medan. Sampel penelitian ditentukan secara cluster sampling, satu kelas sebagai kelas eksperimen dibelajarkan dengan model pembelajaran inquiry training dan satu kelas kontrol dibelajarkan secara konvensional. Instrumen penelitian terdiri atas tes keterampilan proses sains dan tes kreativitas. Data dianalisis secara deskriftif dan inferensial. Analisis deskriftif mendiskripsikan keterampilan proses sains dan kreativitas siswa, sedang analisis inferensial untuk menguji hipotesis dengan Anova. Hasil penelitian diperoleh sebagai berikut. (1) keterampilan proses sains siswa yang dibelajarkan dengan model pembelajaran inquiry training menggunakan media visual lebih baik daripada yang dibelajarkan secara konvensional; (2) keterampilan proses sains siswa yang memiliki kreativitas tinggi lebih baik daripada siswa dengan kreativitas rendah; dan (3) terdapat interaksi antara model pembelajaran inquiry training dan pembelajaran konvensional dengan kreativitas siswa dalam meningkatkan keterampilan proses sains siswa.
\end{abstract}

Kata kunci: model pembelajaran inquiry training, kreativitas, keterampilan proses sains

\section{THE EFFECTS OF VISUAL MEDIAAND CREATIVITY-ASSISTED INQUIRY TRAINING LEARNING MODEL ON STUDENTS' SCIENCE PROCESS SKILLS}

\begin{abstract}
The goal of this research is to find out the effectsof visual media and creativity-assisted inquiry training learning model on the science process skills of Junior High School students. This study was carried out at Amir Hamzah Junior High School Medan in 2014/2015. The sample was selected through cluster sampling: one experimental class was taught using inquiry training learning model and one control class was taught using conventional learning model. Data were analyzed using descriptive and inferential analysis. While the descriptive analysis was aimed at describing students' science process skills and creativity; inferential analysis, which was done through Anova, was carried out to examine hypotheses. The results of this study show that (1) the science process skills of students who were taught using media visual-assisted inquiry training learning model are better than those of students who were taught using conventional learning model; (2) the science process skills of students who have high creativity are better than those of students who have low creativity; and (3) there is an interaction between inquiry training learning model and conventional learning model with students' creativity in improving students' science process skills.
\end{abstract}

Keywords: Inquiry training learning model, creativity, science process skills

\section{PENDAHULUAN}

Pendidikan sains termasuk fisika memiliki peranan penting dalam meningkatkan kualitas sumber daya manusia yang tangguh, kreatif serta mampu beradaptasi mengikuti perkembangan yang terjadi di masyarakat (Folmer et al, 2009: 233). Untuk mewujudkan hal itu, guru sebagai ujung tombak pendidikan memegang peranan yang sangat penting mengelola pembelajaran sesuai dengan prinsip-prinsip kegiatan belajar mengajar. Guru diharapkan lebih kreatif, inovatif dalam melaksanakan pembelajaran berbasis pada siswa (student center learning) sehingga siswa dapat berkembang seoptimal mungkin. 
Kegiatan pembelajaran sains akan bermakna bila pembelajarannya dilakukan sesuai dengan hakikat sains itu sendiri. Belajar sains bukan hanya mempelajari fakta, hukum, prinsip dan teori tetapi juga mengalami bagaimana proses fakta dan prinsip tersebut diperoleh, pembelajaran tidak terfokus pada guru, tetapi bagaimana membuat siswa aktif membangun pengetahuannya sendiri, menemukan dan mengembangkan fakta dan konsepnya sendiri melalui serangkaian metode ilmiah. Kegiatan dalam metode ilmiah menyediakan pengalaman belajar yang menarik perhatian siswa untuk belajar, siswa dapat melakukan kegiatan sebagaimana layaknya seorang ilmuan menemukan konsep dan prinsip-prinsip dalam fisika, dengan demikian diharapkan keterampilan proses sains siswa meningkat.

Keterampilan proses sains adalah perangkat kemampuan kompleks yang biasa digunakan oleh para ilmuwan dalam melakukan penyelidikan ilmiah ke dalam rangkaian proses pembelajaran. Keterampilan proses sains sangat penting bagi setiap siswa sebagai bekal untuk menggunakan metode ilmiah dalam mengembangkan sains serta diharapkan memperoleh pengetahuan baru atau mengembangkan pengetahuan yang telah dimiliki. Model pembelajaran yang cocok untuk pembelajaran fisika harus memberikan kesempatan kepada siswa secara langsung untuk menemukan, meningkatkan pemahaman ilmu pengetahuannya, meningkatkan produktivitas dalam belajar dan berfikir kreatif yang mendatangkan stimulus dalam diri siswa dengan rasa ingin tahunya yang besar dan memungkinkan siswa tersebut untuk dapat menemukan sendiri materi yang harus dipahaminya. Implementasi Kurikulum 2013 menghendaki pembelajaran sains tidak hanya berorientasi produk melainkan juga proses. Perubahan kurikulum ternyata belum menunjukkan hasil seperti yang diharapkan, sebagian besar pembelajaran masih didominasi oleh guru cenderung diarahkan agar siswa menguasai kemampuan kognitif, sangat jarang diarahkan untuk meningkatkan keterampilan proses sains siswa.

Suasana pembelajaran berorientasi guru juga terjadi di SMP Amir Hamzah Medan. Belajar fisika dilakukan dianggap menghafal rumus matematika sehingga pembelajaran membosankan bagi siswa, sebagaimana dikatakan Abdulrahman dkk (2011:31) bahwa fisika adalah pelajaran yang tidak menarik dan tidak diminati oleh siswa.
Berdasarkan studi pendahuluan yang dilakukan dengan meminta siswa mengemukakan pendapat tentang video pembelajaran, hasilnya yang diingat oleh siswa hanyalah rumus yang tertera pada video tersebut. Kondisi ini menyebabkan rendahnya hasil belajar siswa. Nilai rata-rata ujian kelas untuk pelajaran IPA hanya 68 dengan KKM 75. Terlihat juga pada saat praktikum di laboratorium siswa hanya cenderung mendengar dan mengikuti apa yang diperintahkan guru saja. Kurangnya kreativitas siswa dalam praktikum di laboratorium dan dalam belajar membuat siswa kurang berperan dan aktif dalam kegiatan pembelajaran. Salah satu materi pembelajaran dalam fisika yang kurang dipahami siswa adalah materi alat optik, karena dalam pembelajaran yang selama ini dilakukan siswa cenderung dituntut untuk mengahafalkan rumus-rumusnya saja. Sementara banyak konsep yang harus dijelaskan dengan gambar video yang dapat memperlihatkan keterangan pembiasan cahaya yang terdapat pada alat-alat optik.

Rendahnya hasil belajar dan keterampilan proses sains siswa karena kegiatan pembelajaran belum optimal memfasilitasi siswa. Untuk mengembangkan keterampilan proses sains siswa diperlukan suatu model pembelajaran yang melatih siswa agar trampil melalukan penyelidikan ilmiah dalam menemukan konsep dan prinsip serta hukum-hukum fisika. Salah satu cara yang dapat digunakan adalah melalui penerapan model pembelajaran inquiry training. Untuk memudahkan siswa dan guru dalam pembelajaran optik yang banyak gambar yang perlu diamati oleh siswa maka pembelajaran inquiry training ini dilengkapi dengan media visual.

Model pembelajaran inquiry training dirancang agar siswa terlibat secara langsung ke dalam proses ilmiah yang dilakukan dalam lima fase. Pase pertama, menunjukkan suatu peristiwa yang membingungkan siswa sehingga siswa mulai berhasrat untuk menyelidikinya lebih dalam. Fase kedua, mengajukan pertanyaan. Setiap pertanyaan, bagaimanapun harus dijawab dengan kata "ya" dan "tidak". Fase ketiga, setelah fakta dikumpulkan, siswa mulai diminta mencoba mengembangkan hipotesis-hipotesis yang seluruhnya dapat menjelaskan apa yang sebenarnya terjadi melalui eksperimen. Pada fase keempat, siswa mengolah informasi yang mereka dapatkan selama pengumpulan merumuskan hipotesis. Pada fase kelima, siswa menganalisis strategi-strategi 
pemecahan masalah yang telah mereka gunakan selama penelitian (Joyce, et al, 2003:179).

Model pembelajaran inquiry training adalah sebuah kegiatan pembelajaran dimana siswa terlibat secara aktif dalam pembelajaran, merumuskan pertanyaan, menyelidiki dan membentuk pengetahuan baru. Melalui penyelidikan siswa dapat meningkatkan keterampilan proses sainsnya. Keterampilan proses sains dinyatakan sebagai kemampuan transfer konsep yang digunakan pada ilmu-ilmu sains yang mencerminkan sikap seorang ilmuan. Keterampilan proses sains mendukung munculnya perilaku sains dan partisipasi aktif siswa, menghasilkan siswa yang terampil meneliti sehingga menghasilkan siswa berperilaku seperti seorang ilmuwan. Dengan demikian, keterampilan proses sains ini sangat penting dikembangkan dalam pembelajaran sains. Aktivitas penyelidikan untuk memecahkan suatu masalah berbagai keterampilan proses akan dapat berkembang jika siswa memiliki kreativitas yang baik.

Kreativitas merupakan kemampuan untuk memberikan gagasan-gagasan baru dan menerapkannya dalam pemecahan masalah. Kreativitas meliputi, baik ciri-ciri aptitude seperti kelancaran, keluwesan, dan keaslian dalam pemikiran, maupun ciri-ciri non aptitude seperti rasa ingin tahu, senang mengajukan pertanyaan, dan selalu ingin mencari pengalaman-pengalaman baru (Semiawan, 2009:32). Kreativitas merupakan faktor pendukung dalam pembelajaran inquiry training dalam mencapai keterampilan proses sains siswa. Siswa dengan kreativitas yang tinggi misalnya akan dapat merumuskan berbagai macam hipotesis dari objek yang diamati serta memiliki beberapa alternatif untuk membuktikan hipotesis yang diajukan. Selain itu, pembelajaran inquiry training dalam pembelajaran alat-alat optik dapat mengembangkan keterampilan proses sains siswa.

\section{METODE}

Populasi dalam penelitian ini adalah seluruh siswa kelas VIII semester II SMP Swasta Amir Hamzah Medan Tahun ajaran 2014/2015 yang berjumlah tiga kelas sebanyak 97 orang. Pengambilan sampel dilakukan dengan cara cluster random class. Sampel diambil sebanyak dua kelas dari jumlah populasi yaitu satu kelas menjadi kelas eksperimen dengan menggunakan model pembelajaran inquiry training dan kelas yang lain menjadi kontrol dengan menggunakan pembelajaran konvensional.

Penelitian ini termasuk jenis penelitian quasi eksperiment, yaitu merupakan penelitian yang bertujuan untuk mengetahui akibat dari "sesuatu" yang dikenakan pada "subjek", yaitu siswa. Penelitian ini melibatkan dua kelas sampel yang diberi perlakuan yang berbeda. Pada kelas eksperimen dengan model pembelajaran inquiry training sedangkan kelas kontrol dengan model pembelajaran konvensional. Desain penelitiannya berupa Two Group Pretes-Postes Design.

Tabel 1. Rancangan Desain Penelitian

\begin{tabular}{lccc}
\hline \multicolumn{1}{c}{ Sampel } & Pretes & Perlakuan & Postes \\
\hline $\begin{array}{l}\text { Kelas } \\
\text { Eksperimen }\end{array}$ & $\mathrm{T}_{1}$ & $\mathrm{X}$ & $\mathrm{T}_{2}$ \\
\hline $\begin{array}{l}\text { Kelas } \\
\text { Kontrol }\end{array}$ & $\mathrm{T}_{1}$ & $\mathrm{Y}$ & $\mathrm{T}_{2}$ \\
\hline $\begin{array}{l}\text { Keterangan : } \\
\mathrm{X}\end{array}$ & & & \\
$\begin{array}{l}\text { : Perlakuan untuk model pembelajaran inquiry training } \\
\text { berbantuan media visual }\end{array}$ \\
$\mathrm{Y}$ & $:$ Perlakuan untuk model pembelajaran konvensional.
\end{tabular}

Variabel penelitian terdiri dari variabel bebas, variabel moderator dan variabel terikat. Variabel bebas yaitu model pembelajaran inquiry training berbantuan media visual dan model pembelajaran konvensional. Variabel moderator adalah kreativitas siswa, sedang variabel terikat adalah keterampilan proses sains (KPS) pada materi pokok alat-alat optik.

Data yang diperoleh dalam penelitian di analisis secara deskriftif dan inferensial. Analisis deskriftif bertujuan untuk mendiskripsikan keterampilan proses sains dan kreativitas siswa. Analisis inferensial untuk menguji hipotesis penelitian dilakukan dengan anava. Sebelum dilakukan uji hipotesis terlebih dahulu dilakukan uji normalitas dan homogenitas. Selanjutnya karena Ho ditolak dilanjutakan uji lanjut dengan Scheffe Test karena isi sel tak sama menggunakan bantuan software SPSS 17.

\section{HASIL DAN PEMBAHASAN \\ Hasil Penelitian}

Analisis Deskriptif Keterampilan Proses Sains

Hasil analisis deskriptif keterampilan proses sains (KPS) disajikan pada Tabel 2. 
Tabel 2. Deskripsi Skor KPS Kelas Eksperimen dan Kontrol

\begin{tabular}{lccccc}
\hline KPS & N & Minimum & Maximum & Mean & Std. Deviation \\
\hline Pretes Eksperimen & 33 & 10.00 & 74.00 & 42.48 & 13.54 \\
Postes Eksperimen & 33 & 70.00 & 96.00 & 83.64 & 8.65 \\
Pretes_Kontrol & 32 & 16.00 & 56.00 & 39.06 & 11.44 \\
Postes Kontrol & 32 & 58.00 & 92.00 & 73.75 & 8.20 \\
Valid N (listwise) & 32 & & & & \\
\hline
\end{tabular}

Tabel 3. Hasil Uji Normalitas Pretes dan Postes KPS

\begin{tabular}{lcccccc}
\hline \multicolumn{1}{c}{ Kelas } & \multicolumn{3}{c}{ Pretes } & \multicolumn{3}{c}{ Postes } \\
\hline & Statistic & Df & Sig. & Statistic & Df & Sig. \\
Eksperimen & .090 & 33 & .200 & .148 & 33 & .065 \\
Kontrol & .103 & 32 & .200 & .134 & 32 & .151 \\
\hline
\end{tabular}

Lilliefors Significance Correction

Tabel 4. Homogenitas KPS Kelas Eksperimen dan Kelas Kontrol

\begin{tabular}{llccrc}
\hline KPS & & Levene Statistic & df1 & df2 & Sig. \\
\hline Pretes & Based on Mean & .107 & 1 & 63 & .745 \\
& Based on Median & .109 & 1 & 63 & .743 \\
& $\begin{array}{l}\text { Based on Median and } \\
\text { with adjusted df }\end{array}$ & .109 & 1 & 56.387 & .743 \\
& Based on trimmed mean & .113 & 1 & 63 & .738 \\
Postest & 1.482 & 1 & 63 & .228 \\
& Based on Mean & 1.498 & 1 & 63 & .226 \\
& Based on Median & 1.498 & 1 & 58.058 & .226 \\
& Based on Median and with & & & & \\
& adjusted df & & & & \\
& Based on trimmed mean & 1.464 & 1 & 63 & .231 \\
\hline
\end{tabular}

Tabel 5. Uji-t Pretes KPS Kelas Eksperimen dan Kontrol

\begin{tabular}{|c|c|c|c|c|c|c|c|c|c|c|}
\hline & & \multicolumn{3}{|c|}{$\begin{array}{l}\text { Levene's Test } \\
\text { for Equality of } \\
\text { Variances }\end{array}$} & \multicolumn{4}{|c|}{ t-test for Equality of Means } & \multirow{2}{*}{\multicolumn{2}{|c|}{$\begin{array}{c}95 \% \text { Confidence } \\
\text { Interval of the } \\
\text { Difference }\end{array}$}} \\
\hline & & & & & & & & & & \\
\hline & & $\mathrm{F}$ & Sig. & $\mathrm{T}$ & Df & $\begin{array}{c}\text { Sig. } \\
\text { (2-tailed) }\end{array}$ & $\begin{array}{c}\text { Mean } \\
\text { Difference }\end{array}$ & $\begin{array}{l}\text { Std. Error } \\
\text { Difference }\end{array}$ & Lower & Upper \\
\hline \multirow[t]{2}{*}{$\begin{array}{l}\text { Pretes } \\
\text { KPS }\end{array}$} & $\begin{array}{l}\text { Equal } \\
\text { variances } \\
\text { assumed }\end{array}$ & .107 & .745 & 1.099 & 63 & .276 & 3.42 & 3.11 & -2.79 & 9.64 \\
\hline & $\begin{array}{l}\text { Equal } \\
\text { variances not } \\
\text { assumed }\end{array}$ & & & 1.102 & 61.855 & .275 & 3.42 & 3.11 & -2.78 & 9.63 \\
\hline
\end{tabular}

\section{Persyaratan Analisis}

Sebelum dilakukan uji hipotesis dengan anava, terlebih dahulu dilakukan uji persyaratan analisis data yaitu uji normalitas, uji homogenitas dan uji kesamaan rata-rata pretes. Hasil pengujian normalitas KPS pada kedua kelompok pembelajaran dilakukan dengan uji kolmogorov-smirnov dapat dilihat pada Tabel 3 .
Data di atas menunjukkan nilai sig. $>0,05$. Hal ini berarti data kedua kelompok pembelajaran berdistribusi normal. Hasil pengujian homogenitas KPS pada kedua kelompok pembelajaran dengan uji Levene dapat dilihat pada Tabel 4.

Data di atas menunjukkan nilai sig. $>0,05$. Hal ini berarti data kedua kelompok pembelajaran memiliki varians yang homogen. Tahap akhir uji prasyarat analisis adalah menentukan kesamaan 
Tabel 6. Rangkuman Data Hasil Penelitian Persiapan Perhitungan anava

\begin{tabular}{lcccc}
\hline \multirow{2}{*}{ Parameter } & \multicolumn{2}{c}{ Model Pembelajaran $(\mathrm{A})$} & \multirow{2}{*}{ Rata-rata } \\
\hline Tingkat & Kreativitas Tinggi $\left(\mathrm{B}_{1}\right)$ & 89,18 & 75,71 & 82,45 \\
Kreativitas $(\mathrm{B})$ & Kreativitas Rendah $\left(\mathrm{B}_{2}\right)$ & 77,75 & 72,22 & 74,99 \\
& Rata-rata & 83,64 & 73,75 & \\
\hline
\end{tabular}

Tabel 7. Ringkasan Data Hasil Perhitungan anava Faktorial 2 × 2

\begin{tabular}{lrrrrr}
\hline Source & $\begin{array}{c}\text { Type III Sum } \\
\text { of Squares }\end{array}$ & Df & Mean Square & \multicolumn{1}{c}{ F } & \multicolumn{1}{c}{ Sig. } \\
\hline Corrected Model & $2760.100^{\mathrm{a}}$ & 3 & 920.033 & 16.958 & .000 \\
Intercept & 399257.505 & 1 & 399257.505 & 7359.165 & .000 \\
Model_Pembelajaran & 1452.306 & 1 & 1452.306 & 26.769 & .000 \\
Tingkat_Kreativitas & 896.318 & 1 & 896.318 & 16.521 & .000 \\
Model_Pembelajaran * & 253.536 & 1 & 253.536 & 4.673 & .035 \\
Tingkat_Kreatifitas & & & & & \\
Error & 3309.439 & 61 & 54.253 & & \\
Total & 409368.000 & 65 & & & \\
Corrected Total & 6069.538 & 64 & & & \\
a. R Squared $=.455$ (Adjusted R Squared $=.428)$ & & & & \\
\hline
\end{tabular}

pretes KPS kedua kelompok pembelajaran. Hasil uji kesamaan Rata-rata pretes dilakukan dengan uji-t dua pihak, hasilnya dapat dilihat pada Tabel 5 .

Data tabel 5 menunjukkan nilai sig. $>0,05$. Berdasarkan hasil tersebut disimpulkan bahwa tidak ada perbedaan pretes KPS kedua kelompok pembelajaran, dengan kata lain kedua kelompok pembelajaran memiliki kemampuan awal yang sama. Setelah dilakukan uji persyaratan analisis data selanjutnya dilakukan pengujian hipotesis. Untuk persiapan uji hipotesis dilakukan perhitungan rata-rata KPS untuk tiap kelompok. Rangkuman data hasil penelitian persiapan untuk anava dapat dilihat pada Tabel 6.

Berdasarkan Tabel 6, selanjutnya diolah dengan teknik analisis varians faktorial $2 \times 2$, dan diperoleh ringkasan hasil perhitungan uji anava seperti pada Tabel 7.

Berdasarkan hasil pengujian hipotesis seperti data tabel di atas temukan sebagai berikut: (1) Keterampilan proses sains siswa yang dibelajarkan model pembelajaran inquiry training lebih baik daripada pembelajaran konvensional. Rata-rata keterampilan proses sains siswa yang dibelajarkan dengan model pembelajaran inquiry training adalah 83,64 dan untuk pembelajaran konvensional adalah 73,75 . Keterampilan proses sains pada kedua kelompok siswa ini dapat dilihat pada Gambar 1 .

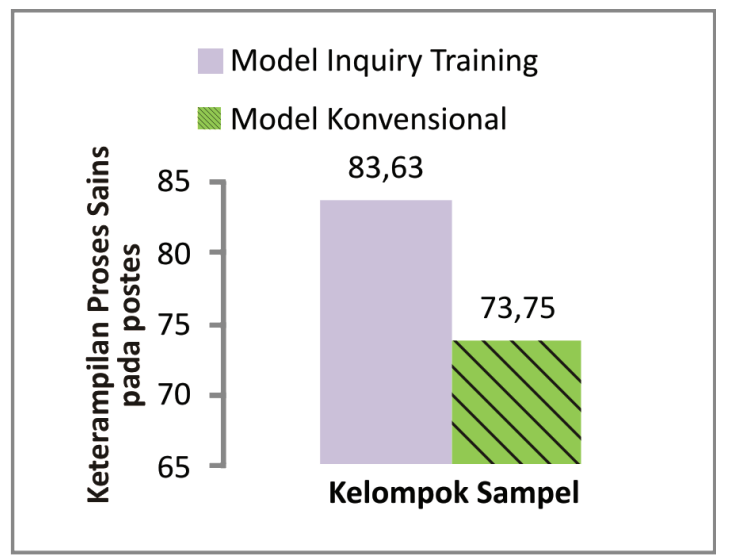

Gambar 1. Skor Keterampilan Proses Sains

(2) Keterampilan proses sains siswa yang memiliki kreativitas tinggi lebih baik dari pada siswa yang memiliki kreativitas rendah. Diagram perbandingan kreativitas tinggi dan rendah berdasarkan hasil keterampilan proses sains yang menggunakan model pembelajaran inquiry training dan pembelajaran konvensional dapat dilihat pada Gambar 2. 


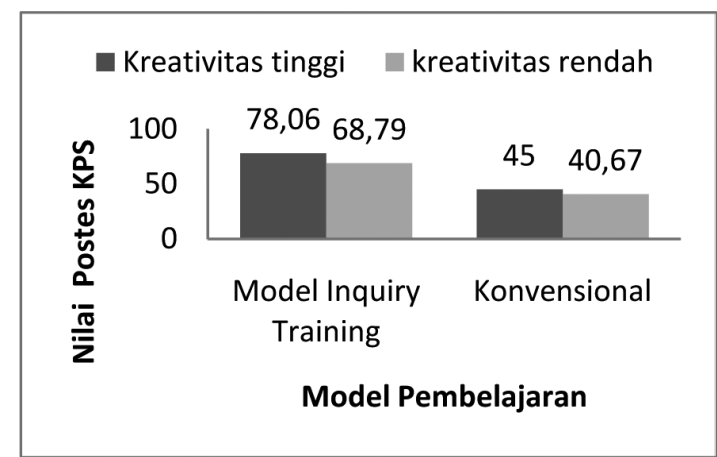

Gambar 2. Diagram Batang Skor Kreativitas Siswa

(3) Terdapat interaksi model pembelajaran inquiry training dan konvensional dengan kreativitas terhadap keterampilan proses sains. Interaksi antara model pembelajaran dan kreativitas terhadap keterampilan proses sains siswa, ditunjukkan pada Gambar 3 berikut :

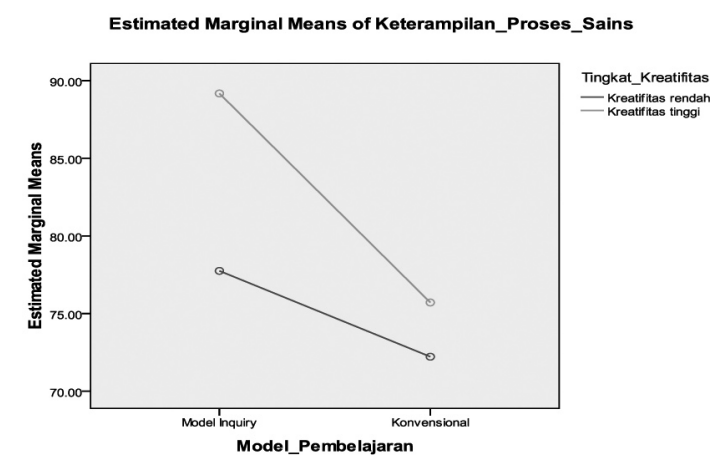

Gambar 3. Garis Interaksi Model

\section{Pembelajaran dan Kreativitas terhadap Kete- rampilan Proses Sains}

Untuk melihat bentuk interaksi antara model pembelajaran dan tingkat kreativitas terhadap keterampilan proses sains siswa, dilakukan uji lanjut dengan menggunakan Scheffe Test. Adapun ringkasan hasil perhitungan Scheffe Test dapat dilihat pada Tabel 8 .

Dari berbagai hasil analisis data dari tabel di atas menunjukkan hal-hal sebagai berikut.

(1) Ada perbedaan keterampilan proses sains siswa yang dibelajarkan dengan model pembelajaran inquiry training yang memiliki kreativitas tinggi dan rendah. Hal ini membuktikan bahwa kreativitas sangat mempengaruhi hasil keterampilan proses sains siswa. Dengan model pembelajaran yang sama, siswa dengan kreativitas belajar yang tinggi memperoleh hasil yang lebih baik dibandingkan siswa dengan tingkat kreativitas belajar rendah.

(2) Ada perbedaan keterampilan proses sains antara siswa yang dibelajarkan dengan model pembelajaran inquiry training dan konvensional untuk siswa yang memiliki kreativitas tinggi. Hal ini membuktikan bahwa model pembelajaran sangat mempengaruhi keterampilan proses sains siswa. Dengan model pembelajaran yang berbeda, siswa dengan model pembelajaran inquiry training memperoleh hasil yang lebih baik dibandingkan

Tabel 8. Ringkasan Hasil Perhitungan Scheffe Test

\begin{tabular}{|c|c|c|c|c|c|c|}
\hline $\begin{array}{c}\text { (I) } \\
\text { Jenis }\end{array}$ & $\begin{array}{c}\text { (J) Jenis } \\
2\end{array}$ & $\begin{array}{c}\text { Mean Difference } \\
(\mathrm{I}-\mathrm{J})\end{array}$ & $\begin{array}{l}\text { Std. } \\
\text { Error }\end{array}$ & Sig. & \multicolumn{2}{|c|}{$\begin{array}{l}95 \% \text { Confidence Interval } \\
\text { Lower } \\
\text { Bound }\end{array}$} \\
\hline & $11.4265^{*}$ & & 2.56558 & .001 & 4.0501 & \\
\hline & 3 & $13.4622^{*}$ & 2.65830 & .000 & 5.8192 & 21.1052 \\
\hline & 4 & $16.9542^{*}$ & 2.49107 & .000 & 9.7921 & 24.1164 \\
\hline \multirow[t]{3}{*}{2} & 1 & $-11.4265^{*}$ & 2.56558 & .001 & -18.8029 & -4.0501 \\
\hline & 3 & 2.0357 & 2.69556 & .903 & -5.7144 & 9.7858 \\
\hline & 4 & 5.5278 & 2.53079 & .201 & -1.7486 & 12.8041 \\
\hline \multirow[t]{3}{*}{3} & 1 & $-13.4622^{*}$ & 2.65830 & .000 & -21.1052 & -5.8192 \\
\hline & 2 & -2.0357 & 2.69556 & .903 & -9.7858 & 5.7144 \\
\hline & 4 & 3.4921 & 2.62474 & .624 & -4.0544 & 11.0386 \\
\hline \multirow[t]{3}{*}{4} & 1 & $-16.9542^{*}$ & 2.49107 & .000 & -24.1164 & -9.7921 \\
\hline & 2 & -5.5278 & 2.53079 & .201 & -12.8041 & 1.7486 \\
\hline & 3 & -3.4921 & 2.62474 & .624 & -11.0386 & 4.0544 \\
\hline
\end{tabular}

Based on observed means.

The error term is Mean Square(Error) $=54.253$.

*. The mean difference is significant at the 0.05 level. 
siswa dengan pembelajaran konvensional walau siswa pada kedua kelompok memiliki tingkat kreativitas belajar yang tinggi.

(3) Terdapat perbedaan keterampilan proses sains siswa yang dibelajarkan dengan model pembelajaran inquiry training yang memiliki tingkat kreativitas tinggi dengan pembelajaran konvensional yang memiliki tingkat kreativitas rendah. Hal ini membuktikan bahwa model pembelajaran dan kreativitas belajar sangat mempengaruhi keterampilan proses sains siswa. Tingkat kreativitas belajar dan model pembelajaran yang berbeda, siswa dengan tingkat kreativitas belajar yang tinggi dan diberikan model inquiry training memperoleh hasil keterampilan proses sains yang lebih baik dibandingkan siswa dengan tingkat kreativitas belajar rendah yang diberi pembelajaran konvensional.

(4) Tidak ada perbedaan keterampilan proses sains siswa yang dibelajarkan dengan model pembelajaran inquiry training dan konvensional untuk siswa yang memiliki tingkat kreativitas rendah. Hal ini dapat diperoleh karena siswa di kedua kelompok memiliki tingkat kreativitas belajar yang rendah sehingga walaupun model pembelajaran yang diberikan berbeda tetap menghasilkan keterampilan proses sains yang relatif sama.

\section{Pembahasan}

\section{Efek Model Pembelajaran terhadap Keteram- pilan Proses Sains}

Hipotesis pertama untuk mengetahui keterampilan proses sains yang dibelajarkan dengan model pembelajaran yang berbeda. Hasil uji hipotesis menunjukkan bahwa keterampilan proses sains siswa yang dibelajarkan menggunakan model inquiry training berbantuan media visual lebih baik daripada yang dibelajarkan menggunakan model konvensional. Secara empirik hasil penelitian ini sejalan hasil penelitian Simsek dan Kabapinar (2010:1190-1191); Vaishnav (2013:1219); Abdi (2014:37) memperoleh bahwa hasil belajar dan keterampilan proses sains siswa dengan model pembelajaran inkuiri berbeda dengan hasil belajar konvensional. Selain itu Ergul, et.al (2011:63) memperoleh bahwa metode inquiry based teaching dapat meningkatkan keterampilan proses sains siswa.

Penyebabnya adalah karena kegiatan model pembelajaran inquiry training berbantuan me- dia visual berupa video pembelajaran membuat pembelajaran menarik dan menyenangkan bagi siswa. Video pembelajaran membantu siswa memahami konsep optik yang abstrak, karena salah satu alasan utama kesulitan siswa belajar fisika adalah konsepnya yang abstrak, penuh teori dan rumus matematis (Suzuk, et. al. 2011:66). Penggunaan video yang didalamnya terdapat gambargambar yang menarik dan jelas tentang pembiasan dan pemantulan pada alat-alat optik membuat pembelajaran menarik bagi siswa. Siswa dapat melakukan pengulangan pada bagian yang sulit dipahami sehingga mempermudah siswa untuk membentuk konsep melalui pengalaman yang diperolehnya.

Pembelajaran dengan inquiry training lebih efektif mengembangkan keterampilan proses sains siswa dikarenakan indikator-indikator keterampilan proses sains sangat relevan dan terintergrasi dalam langkah-langkah pembelajaran inquiry training. Indikator-indikator keterampilan porses sains yang terdiri dari melakukan pengamatan (observasi), inferensi, mengajukan pertanyaan, menafsirkan hasil pengamatan (interpretasi), mengelompokkan (klasifikasi), meramalkan (prediksi), berkomunikasi, membuat hipotesis, merencanakan percobaan atau penyelidikan, menerapkan konsep atau prinsip, dan keterampilan menyimpulkan semuanya dapat berkembang dalam pembelajaran inquiry training.

Fase pertama pembelajaran inquiry training adalah menyajikan masalah atau pertanyaan dengan cara guru mengajukan situasi permasalahan yang dapat membingungkan siswa (puzzle event) dapat melatih siswa memilki keterampilan meramalkan/memprediksi jawaban dari permasalahan, melatih siswa mengajukan pertanyaan untuk mencari jawaban dari permasalahan yang diberikan guru dan jawaban yang diberikan guru hanya sebatas kata ya atau tidak sehingga siswa merasa tertantang untuk mencari jawabannya. Mengamati dan mengajukan pertanyaan sangat diperlukan dalam pembelajaran sebagaimana dikatakan Siswanto, dkk (2014:115) bertanya dan menjawab pertanyaan itu sangat penting tanpa memperdulikan apa isi dari yang mereka tanyakan, karena dapat meningkatkan keterampilan proses sains siswa.

Pada fase kedua, siswa mengumpulkan informasi tentang peristiwa yang mereka lihat/ amati dapat melatih kemampuan siswa dalam mengamati atau mengobservasi suatu kejadian, 
mengelompokkan/mengklasifikasi informasiinformasi yang telah mereka dapatkan. Informasi yang diperoleh digunakan sebagai dasar untuk merumuskan hipotesis sehingga dapat meningkatkan keterampilan sains siswa dalam merumuskan hipotesis.

Pada fase ketiga, siswa diberi kesempatan untuk melakukan eksperimen dimana mereka menjawab permasalahan yang diberikan guru melalui ekseprimen sehingga pada fase ini siswa akan terlatih merencanakan suatu penyelidikan dan menggunakan alat/bahan/ dan sumber yang mereka dapatkan dari fase sebelumnya. Dalam eksperimen siswa mengalami dan melakukan pengukuran, mencatat hasil pengukuran, menghubungkan hasil pengamatan serta menemukan pola atau keteraturan dari hasil pengamatan yang ditemukan untuk menarik kesimpulan. Semua aktivitas ini mendukung pengembangan keterampilan proses sains siswa. Selain itu siswa menemukan dan membangun sendiri pengetahuannya. Pemahaman yang dibangun berdasarkan pengalaman yang diperoleh siswa membuat pembelajaran pembelajaran menjadi lebih bermakna bagi siswa (Mulbar, 2015:279).

Pada fase keempat siswa dapat dilatih menerapkan konsep yang mereka dapat baik dari eksperimen maupun dari hasil pengalaman dan pemikiran siswa. Partisipasi dalam kegiatan eksperimen melatih siswa menggunakan alat, mengumpulkan data, membuat prediksi, inferensi, menafsirkan data, serta mengkomunikasikan temuan yang melibatkan keterampilan proses sains siswa.

Keterlibatan siswa dalam pembelajaran inquiry training memberikan banyak pengalaman dan membiasakan siswa bekerja ilmiah atau penelitian seperti melakukan pengamatan, komunikasi, interpretasi, bereksperimen, menarik kesimpulan dan sebagainya. Hal ini sesuai dengan penelitian Sopiah dkk (2009:17) bahwa dengan perangkat pembelajaran inkuiri meningkatkan keterampilan bekerja ilmiah siswa. Kegiatan-kegiatan ilmiah dikembangkan melalui pengalaman-pengalaman langsung sebagai pengalaman belajar. Melalui pengalaman langsung, seseorang dapat lebih menghayati proses atau kegiatan yang sedang dilakukan. Aktivitas siswa terlibat langsung dalam penyelesaian masalah mulai dari mengidentifikasi masalah, mengamati, merumuskan hipotesis hingga pemilihan solusi penyelesaian masalah membutuhkan keterampilan berpikir tingkat tinggi (Saguni, 2013:216). Pembelajaran yang membutuhkan keterampilan berpikir tingkat tinggi akan mengembangkan keterampilan proses sains siswa.

Hal ini bertolak belakang dengan pembelajaran konvensional yang memiliki ciri-ciri berpusat pada guru. Pada pembelajaran konvensional guru memegang peran aktif dalam pembelajaran, seperti menyajikan materi, menjelaskan serta memberikan tugas kepada siswa. Siswa kurang diberi kesempatan berpartisipasi aktif dalam pembelajaran untuk menemukan dan membangun konsep, tidak memiliki pengalaman melakukan kegiatan eksperimen. Pembelajaran hanya mengharapkan siswa menghafal konsep dan rumus-rumus fisika sehingga pembelajaran membosankan bagi siswa. Dengan demikian keterampilan proses sains sulit dikembangkan dalam pembelajaran konvensional.

\section{Efek Kreativitas terhadap Keterampilan Proses Sains}

Hipotesis dua untuk mengetahui keterampilan proses sains siswa yang memiliki kreativitas yang berbeda. Hasil uji hipotesis menunjukkan bahwa keterampilan proses sains siswa yang memiliki kreativitas tinggi lebih baik daripada siswa yang memiliki kreativitas rendah. Hasil penelitian ini sejalan dengan temuan Deta dkk (2013:32) bahwa ada perbedaan prestasi belajar afektif siswa antara siswa dengan kreativitas tinggi dan rendah. Siswa dengan kreativitas tinggi lebih empati terhadap teman satu kelompok, tepat waktu dalam melaksanakan percobaan, dan rajin dalam mengerjakan tugas. Hal ini disebabkan karena siswa dengan kreativitas tinggi lebih cepat dan tanggap dalam memecahkan suatu masalah dan lebih bersemangat.

Pada awal pembelajaran guru meminta siswa mengajukan pertanyaan berkaitan dengan objek yang diamati siswa. Aspek keterampilan proses yang dikembangkan pada langkah awal adalah kemampuan mengajukan pertanyaan, kemampuan mengkomunikasikan pertanyaan dan jawaban serta melakukan sanggahan jika ada yang tidak sesuai. Siswa dengan kreativitas tinggi memiliki kemampuan menyelesaikan suatu permasalahan mengutamakan keterampilan penalaran, mengajukan pertanyaan yang bervariasi, berani mengemukan jawaban dan pertanyaan yang berbeda dari yang lain serta tidak takut salah. Sebaliknya karakteristik siswa dengan kreativitas 
rendah selalu mengharapkan bimbingan dari guru, takut berbuat, sulit mendapatkan alternatif penyelesaian masalah, malu mengemukakan pertanyaan dan jawaban karena takut salah. Selain itu dalam memecahkan suatu masalah kurang melibatkan kemampuan penalaran.

Kreativitas merupakan keterampilan fisik dan mental terkait dengan kemampuan-kemampuan yang mendasar yang dimiliki, dikuasai, dan diaplikasikan dalam suatu kegiatan ilmiah, sehingga para ilmuan berhasil menemukan sesuatu yang baru.Dengan mengembangkan keterampilan proses nantinya siswa akan mampu menemukan dan mengembangkan sikap dan nilai yang dituntut (Semiawan, 1992:12).

Dalam pembelajaran permasalahan yang disajikan guru cenderung bersifat terbuka sehingga lebih mudah dikerjakan oleh siswa dengan kreativitas tinggi. Pada langkah ketiga, setelah fakta dikumpulkan, siswa diminta mengembangkan hipotesis-hipotesis yang seluruhnya dapat menjelaskan apa yang sebenarnya terjadi melalui eksperimen. Pada tahap kempat, siswa mengolah informasi yang mereka dapatkan selama pengumpulan merumuskan hipotesis. Pada tahap kelima, siswa menganalisis strategi-strategi pemecahan masalah yang telah mereka gunakan selama penelitian. Siswa dengan kreativitas tinggi dapat memberikan beberapa hipotesis, mampu memprediksi jawaban permasalahan serta mampu merancang dan melaksanakan percobaan untuk membuktikan hipotesis yang diajukan.

Jika hipotesis yang diajukan tidak terbukti siswa dengan kemampuan berpikir lancar sebagai aspek dari kreativitas dapat mencari alternatif pemecahan masalah dengan berbagai macam ide yang original, dapat mengatasi berbagai situasi yang dihadapinya dalam kehidupan seharihari. Sementara siswa yang memiliki kreativitas rendah akan merasa kesulitan menyelesaikan masalah, jika terjadi kendala siswa akan putus asa dan tidak mampu melaksanakan kegiatan belajarnya secara efektif. Hal inilah yang menyebabkan bahwa siswa dengan kereativitas tinggi memiliki keterampilan proses sains lebih tinggi dari siswa dengan kereativitas rendah.

\section{Interaksi Model Pembelajaran dan Kreativi- tas terhadap Keterampilan Proses Sains}

Hipotesis tiga untuk mengetahui perbedaan keterampilan proses sains siswa yang memiliki kreativitas yang berbeda dan dibelajarkan dengan model pembelajaran yang berbeda. Hasil penelitian menunjukkan adanya interaksi antara model pembelajaran inquiry training dan kreativitas terhadap keterampilan proses sains. Siswa dengan kreativitas tinggi jika dibelajarkan dengan model inquiry training memperoleh skor keterampilan proses sains yang lebih tinggi. Hal senada Rahayu dkk (2011:106-110); Deta dkk (2013:28-34) menyatakan bahwa bahwa kemampuan berpikir kreatif dapat meningkatkan keterampilan proses sains dan siswa dengan kreativitas tinggi memiliki hasil belajar paling baik dibandingkan kelompok lainnya. Siswa dengan kreativitas lebih tinggi lebih empati terhadap teman satu kelompok, tepat waktu dalam melaksanakan percobaan dan rajin dalam mengerjakan tugas, cenderung cepat dan tanggap dalam menyelesaikan permasalahan yang terdapat dalam pelaksanaan percobaan. Dengan demikian kreativitas sangat dibutuhkan dalam pembelajaran inquiry training agar tercapai keterampilan proses sains. Indikator kreativitas yaitu berpikir original, berpikir lancar, berpikir luwes dan berpikir terperinci semuanya mendukung pencapaian keterampilan proses sains.

Model pembelajaran inquiry training memberikan kebebasan bagi siswa untuk mendesain proses pembelajaran yang mereka inginkan, sesuai dengan tujuan pembelajaran yang tertera dalam permasalahan. Solusi dari masalah diperoleh melalui kegiatan eksperimen dengan melakukan minds on dan hands on. Partisipasi siswa dalam kegiatan penyelidikan melalui eksperimen mendorong siswa untuk mengajukan pertanyaan, mengajukan hipotesis, membuat prediksi, menggunakan alat-alat untuk mengumpulkan dan menganalisis data, membuat kesimpulan, membangun argumen, mengkomunikasikan temuan, dan menggunakan strategi penalaran luas yang melibatkan keterampilan berpikir kritis, kreatif, kausal, dan berpikir logis (Chin \& Chia, 2005:44-67).

Langkah-langkah pembelajaran inquiry training mulai dari mengidentifikasi masalah, mengajukan pertanyaan, merumuskan hipotesis, mengumpul data, menganalisis dan menyimpulkan data serta mengkomunikasikannya dapat dilakukan dengan baik oleh siswa dengan kreativitas tinggi. Pada fase awal guru meminta siswa mengajukan pertanyaan tentang objek pertanyaan yang hanya bisa dijawab guru dengan kata ya atau tidak. Pada fase ini siswa diharapkan mengemukakan banyak pertanyaan yang bervariasi, mampu 
melihat masalah dari berbagai macam sudut pandang, memberikan macam-macam penafsiran (interpretasi) terhadap masalah yang hanya dapat dilakukan oleh siswa dengan kreativitas tinggi karena memiliki kemampuan berpikir lancar dan luwes.

Sebaliknya, siswa dengan kreativitas rendah selalu mengajukan pertanyaan yang meminta guru menjelaskan karena sulit mengajukan pertanyaan yang mengarah kepada hipotesis yang akan diajukan. Pada fase merumuskan hipotesis siswa diharapkan mampu memprediksi serta menginterpretasi jawaban masalah secara abstrak, dapat mengembangkan gagasan untuk menguji hipotesis, dengan demikan agar terlaksana dengan baik diperlukan kemampuan berpikir lancar, luwes dan terperinci. Pada fase melaksanakan eksperimen siswa dituntut agar dapat melaksanakan eksperimen secara cepat dan tepat, jika ada yang tidak cocok siswa dengan kreativitas tinggi segera dapat mengulang kembali eksperimen dan memperbaiki hasil penyelidikannya. Fase mengkomunikasikan dibutuhkan kemampuan berpikir original dan berpikir lancar. Siswa dengan kemampuan berpikir original penuh percaya diri mampu menyajikan hasil yang diperoleh meskipun berbeda dari pendapat pada umumnya sekaligus dapat mengambil kesimpulan atas pertimbangannya sendiri. Dengan demikian, kreativitas siswa pada pembelajaran inquiry training mendukung pencapaian keterampilan proses sains siswa.

\section{SIMPULAN}

Berdasarkan analisis data dari hasil penelitian yang telah dilakukan dapat dikemukakan beberapa kesimpulan sebagai berikut. Pertama, model pembelajaran inquiry training menggunakan media visual lebih baik dalam meningkatkan keterampilan proses sains siswa daripada pembelajaran konvensional. Kedua, hasil keterampilan proses sains siswa yang memiliki kreativitas tinggi lebih baik dibandingkan dengan siswa yang memiliki kreativitas rendah. Ketiga, terdapat interaksi model pembelajaran inquiry training dan konvensional dengan kreativitas terhadap keterampilan proses siswa.

\section{UCAPAN TERIMAKASIH}

Ucapan terimakasih kami sampaikan kepada: Ibu Siti Fatimah, S.Pd selaku Kepala SMP Amir Hamzah Medan, yang telah banyak membantu sehingga penelitian ini dapat terlaksana den- gan lancar. Kepada Prof. Sahyar, M.Si, M.M, Dr. Ridwan A. Sani, Prof Nurdin Bukit, M.Si, selaku narasumber yang telah banyak membimbing tim peneliti dalam pelaksanaan penelitian.

\section{DAFTAR PUSTAKA}

Abdi, Ali. 2014. "The Effect of Inquiry-based Learning Method on Students' Academic Achievement in Science Course". Universal journal of Education Reseach 2(1): $37-41$.

Abdulrahman, Liliasari, A. Rusli, \& Waldrip, Bruce, 2011. "Implementasi Pembelajaran Berbasis Multirepresentasi untuk Peningkatan Penguasaan Konsep Fisika Kuantum", dalam Cakrawala Pendidikan, Jurnal Ilmiah Pendidikan XXX (1) hlm 30-45.

Chin, C \& Chia, L. 2005. Problem-Based Learning: Using Ill-Structured Problem in Biology Project Work. Science Education. 90 (1). 44-67.

Deta, U. A, Suparmi, S. Whida. "Pengaruh Metode Inkuiri Terbimbing dan Proyek, Kreativitas, serta Keterampilan Proses Sains terhadap Prestasi Belajar Siswa". Jurnal Pendidikan Fisika Indonesia 9 (2013), 28-34.

Ergul, R., Yeter, S., Sevgul, C., Zehra, O., Sirin, G., Meral, S. 2011. "Effect of Inquiry-base Science Teaching on Elementary Scholl Students' Science Process Skills and Science Attitude". Bulgarian Journal for the Scholarship of Teaching and Learning. Vol.5. No.1: 49-68.

Folmer, V., Barbosa, N. B. V. Soares, F. A., \& Rocha, J. B. T. 2009. "Eksperimental Activies Base on Ill- Structured Problem Brazilian School Understanding of Nature of Scientific Knowledge". Journal of Research in Science Teaching. 8 (1) hlm 232-254.

Joyce Bruce, Marsha Weil and Emily Calhoun. 2013. Models of Teaching, Eight Edition. New Jersey: Allyn and Bacon.

Mulbar, Usman, 2015. "Pengembangan Desain Pembelajaran Matematika dengan Meman- 
faatkan Sistem Sosial Masyarakat". Jurnal Cakrawala Pendidikan, Juni 2015, Tahun XXXIV, No.2, 278-287.

Rahayu, E., Susanto, H., \& Yulianti, D. 2011. "Pembelajaran Sains dengan Pendekatan Keterampilan Proses untuk Meningkatkan Hasil belajar dan Kemampuan Berpikir Kreatif Siswa". Jurnal Pendidikan Fisika Indonesia, Vol. 7 No. 2 :106-110.

Saguni, Fatimah. 2013. Efektivitas Metode Problem Base Learning, Cooperative Learning Type Jigsaw dan Ceramah sebagai Problem Solving dalam Mata Kuliah Perencanaan Pembelajaran. Jurnal Cakrawala Pendidikan, Juni 2013, Tahun XXXII, No.2, 207-219.

Semiawan, C.R. 2009. Kreativitas Keberbakatan. Jakarta : PT. Indeks.

Semiawan, C.R. 1992. Kreativitas Keberbakatan. Jakarta : PT. Indeks.

Simsek, P. \& Kabapinar, F. 2010. "The Effect of Inquiry Base Learning on Elementary Students Conceptual Undestanding of Matter,
Scientifiec Process Skills and Sains Attitudes", Procedia-Social and Behavioral Sciences, Vol 2. 1190-1194.

Sopiah, S. Wiyanto., Sugianto. 2009. "Pembiasaan Bekerja Ilmiah pada Pembelajaran Sains Fisika untuk Siswa SMP”. dalam Jurnal Pendidikan Fisika Indonesia 5(1) 14-19.

Siswanto, Kaniawati, I., \& Suhandi, A. 2014. "Penerapan Model Pembelajaran Pembangkit Argumen Menggunakan metode Saintifik untuk Meningkatkan Kemampuan Kognitif dan Keterampilan Berargumentasi Siswa ". Jurnal Pendidikan Fisika Indonesia, 10 (2): 104-116.

Suzuk, E., M.Ali Corlu, Cem Gurel. 2011. "Students' Perception of Learning Efficiency of Introductory Physics Course". Eurasian Journal of Physics and Chemistry Education (EJPCE): 65-71.

Vaishnav, R. 2013. 'Effectiveness of Inquiry Training for Teaching Science". Scholary Research Journal for Interdisiplinary Studies. Vol.1: 1216-1220. 